\title{
1 Dancing with storks: The role of power relations in Payments for Ecosystem Services
}

2

3

4 Hiroe Ishihara, Unai Pascual and Ian Hodge

6 Abstract

7 The institutional change induced by payments for ecosystem services (PES) schemes is a 'messy' 8 process. The uptake and outcomes of PES schemes cannot be fully explained from a rational 9 choice perspective. The notion of 'institutional bricolage' is needed to analyse how actors

10 assemble or reshape their actions by combining new institutions such as a PES scheme within 11 other locally embedded institutions. A case study from Japan is used to illustrate how a PES 12 scheme designed to conserve the habitat of a charismatic and endangered flagship species, the 13 Oriental White Stork, has been reshaped by social actors to fit the locally dominant 14 'institutional logic'. We also show how the resulting institutional change is not only able to 15 subvert policy makers' original assumptions, for instance about how to target and distribute the 16 payments, but can also contribute to the reproduction of unequal power relations.

18 Keywords

19 Institutional bricolage, power relations, agency, payments for ecosystem services, 20 environmental governance, common pool resources 


\section{Introduction}

23 The use of economic incentives, such as so-called payments for ecosystem services (PES), 24 continues to gain increasing attention in environmental policy circles as an efficient and 25 potentially equitable tool for environmental governance, including the conservation of biodiversity (Pascual et al., 2014). Here PES is defined broadly as a transfer of resources between actors, which aims to create incentives, subject to clear conditions, to align individual and/or collective resource use decisions with the social interest in the management of natural resources (modified from Muradian et al., 2010). The burgeoning research on PES schemes indicates that i) implementation of PES schemes is not a straightforward process as rational choice models might suggest (e.g Osborne, 2011; Rodríguez-de-Francisco and Budds, 2015; Rodríguez de Francisco et al., 2013; Vatn, 2010), ii) there is a high degree of complexity associated with the trade-offs between cost-effectiveness and other policy goals, such as social equity (e.g. Pascual et al., 2010; Pascual and Phelps, 2014), and iii) the introduction of PES impacts on power relations amongst stakeholders (e.g. Milne and Adams, 2012; Rodríguez-de-Francisco and Budds, 2015).

We argue that the introduction of PES schemes is often associated with a layer of complexity because ecosystem service providers are not just suppliers of such services but are also 'institutional bricoleurs' who rearrange the standardised PES-logics in order to 'fit' their own (local) social context. The term 'bricoleurs' implies that actors creatively combine elements from different institutional contexts into a new institutional arrangement (Christiansen, Larke and Lounsbury, 2013). This concept enables us to challenge the view of actors as powerless victims of institutional change. The application of the notion of institutional bricolage is helpful in undertaking power-sensitive analysis of environmental governance and can contribute to the inclusion of power relations into the ecosystem services framework (Berbés-Blázquez et al., 2016; Pascual and Phelps, 2014; Van Hecken et al., 2015). We borrow the term 'institutional bricolage' from cultural anthropology (Douglas, 1986; Lévi-Strauss, 1966) and organisational studies (Christiansen, Larke and Lounsbury, 2013; Lounsbury and Glynn, 2001; Schneiberg, 2002) and adapt it to conceptualise a process in which actors assemble or reshape existing (often local) institutions, such as collective action norms in the management of common pool resources (hereafter CPR), by combining them with a recently introduced PES scheme. We also 
argue that due to institutional bricolage, the introduction of PES can often lead to a 'messy' institutional process with unintended consequences. ${ }^{1}$

54 A case study from a rural community in Japan within Toyoka City is presented to illustrate the application of the idea of 'institutional bricolage' and show how it helps to analyse the ways in which a PES scheme may lead to messy institutional change. This PES scheme has been introduced as an incentive to support the conservation of a flagship endangered species, the Oriental White Stork (Ciconia boyciana), which is on the IUCN Red List of Threatened Species and can only be found in Japan, South Korea, China and Russia. More generally, in Japan, PES approaches have been heralded as tackling the problem of under-use, rather than over-exploitation, of CPRs (see Section 3.1. for a description of problems caused by the under-use of CPRs). Since the 1990s, in Toyoka city, the local government has implemented eco-certification schemes for organic farming and eco-tourism to tackle this problem (Hyogo Prefectural Government, 2009). Toyoka city is considered to be one of the success stories in the use of a broadly defined PES scheme, along with Osaki City and Sado City, where similar schemes supporting flagship species have been implemented (Honda, 2008a; Wittmer and Gundimeda, 2010). ${ }^{2}$

The case study from Toyoka city reveals how community residents act as institutional bricoleurs rearranging the PES-logic to 'fit' their own local context and to reproduce or change the power relations within their community. It illustrates that the implementation of a PES scheme is not just about incentivising people to align their resource use decisions with broader social interests but also about power struggles among stakeholders, such as between policy makers and local residents as well as among the residents themselves.

\footnotetext{
1 'Messy' institutional process does not imply that deliberate institutional design is necessarily impossible. Each actor will act deliberately to achieve their own goal and use their resources to negotiate the institutional outcome. However, we term this process as 'messy' because it is not the deliberation of one actor or one social group, such as the implementer of a PES scheme, which determines the outcome; rather it is determined by the negotiations amongst various stakeholders.
}

${ }^{2}$ Both cities use flagship species similar to that of Toyoka. In Osaki city, the protected species is a goose and in Sado city, it is the crested ibis

For details see;

http://www.biodic.go.jp/biodiversity/shiraberu/policy/pes/satotisatoyama/satotisatoyama01.html

for Osaki city and

http://www.biodic.go.jp/biodiversity/shiraberu/policy/pes/satotisatoyama/satotisatoyama03.html for Sado city. 
The next section introduces the central idea of institutional bricolage from a critical institutionalist perspective. Then, Section 3 describes the background and methodology used in the case study and Section 4 analyses how the PES scheme designed for the conservation of the Oriental White Stork in Toyoka city was contested, altered and articulated by the local community. The paper concludes with the main lessons learnt for future PES-based governance of biodiversity through the lens of institutional bricolage.

\section{Setting the scene: Institutional bricolage, agency, and power}

In recent years the institutionalist school of thought on the study of the commons, often termed critical institutionalism, has emerged to fill the gaps left by mainstream institutionalism led by the work of Elinor Ostrom (e.g. Cleaver, 2012; De Koning and Cleaver, 2012; Hall et al., 2014). The mainstream approach generally understands institutions as 'the rules of the game' which define what actors may (permitted), must (obliged) or may not (forbidden) do (Crawford and Ostrom, 1995; North, 1990). It argues that rational actors design appropriate institutions to fulfil certain functions, for instance to solve collective action problems or information asymmetries (Hotimsky et al., 2006). When carefully crafted, the assumption goes, CPR institutions can in principle curb individuals' selfish incentives to free-ride and enhance collective action to avoid the over-exploitation of the commons (McKean, 1992; Ostrom, 1990; Wade, 1989).

Critical institutionalists emphasize that new institutions cannot be separated from the pre-existing social and cultural embeddedness of resource users and thus the messiness that arises from the multiplicity of their interests and the complexity through social interactions (Cleaver, 2002; Fabinyi et al., 2014; McCay, 2002; Mosse, 1997). For this school of thought, resource users do not hold narrowly defined utilitarian and purely instrumental preferences (Mosse, 1997). Instead they are viewed as holding multiple social identities and rationalities (Schnegg and Linke, 2015). This implies that CPR use cannot be understood solely in terms of a narrow desire to optimise a given objective (e.g. income maximization or risk minimization). It can also be strongly influenced by other concerns and interests stemming from various social identities and roles, as well as being associated with norms relating to authority/respect, in-group loyalty and fairness/reciprocity (Chan et al., 2016). It follows that institutional change relating to CPR use can be motivated, for example, by an elite's desire to reproduce power relations (Hall et al., 2014; Hotimsky et al., 2006). It should also be pointed out that collective action for the conservation of CPR does not necessarily guarantee outcomes that are either socially or ecologically desirable (Ishihara and Pascual, 2009). 
107 Critical institutionalism draws strongly on sociology and anthropology and institutions are 108 understood as "social arrangements that shape and regulate human behaviour and have some 109 degree of permanency and purpose transcending individual human lives and intentions" 110 (Cleaver, 2012, p. 8). The process of institutional change is understood through the idea of 111 'institutional bricolage' (Cleaver, 2002; Galvan, 2004), not as an issue of 'crafting' rules 112 (Ostrom, 1992) or of searching for 'institutional fit' (Young, 2002) but by explicitly 113 acknowledging the 'messy' process or the 'unintended' outcomes that it may produce. The term 114 'bricolage' was originally used by the French anthropologist Levi-Strauss (1966) to describe 115 how the 'savage' mind understands different cultures, and later developed by Douglas (1986) in 116 the context of institutions, who argued that to economise on cognitive effort, actors borrow 117 existing familiar institutions as a 'frame of reference' to understand new and 'unfamiliar' social 118 phenomena. In the study of the commons, the use of the term institutional bricolage refers to "a 119 process through which people, consciously and non-consciously, assemble or reshape 120 institutional arrangements, drawing on whatever materials and resources are available, 121 regardless of their original purpose" (De Koning and Cleaver, 2012, p. 4).

122 This notion of institutional bricolage enables us to better understand human agency and the 123 dynamic power relations involved in the institutional processes that arise in the governance of 124 the commons. At this point, we make two remarks: first, the actors involved in institutional 125 change are not powerless victims of this process, rather they are active 'improvisers'. Drawing 126 on Sewell (1992), we use the term human agency ${ }^{3}$ to refer to actors' capacity to transpose and 127 extend an 'institutional logic' to a new institutional context, where 'institutional logic' is the 128 shared taken-for-granted social prescriptions that guide individual behaviour in an institutional 129 context (Battilana, 2006). The institutional logic thus embodies belief systems and material 130 practices that represent particular worldviews, valued ends, and the appropriate means to 131 achieve such ends (Christiansen, Larke and Lounsbury, 2013). When actors are faced with new 132 situations, they exercise their agency by extending their existing institutional logic and make do 133 with whatever is at hand to fit the new institutional context (Baker and Nelson, 2005).

\footnotetext{
${ }^{3}$ Agency is temporally embedded in the past and is oriented towards the future (Emirbayer and Mische, 1998). On the one hand, because actors are born into a specific social structure, they internalise an institutional logic and follow routines forming habits or habitus (Bourdieu, 1990). On the other hand, actors face unexpected outcomes even when they follow habitus. Then they start to question what they have 'taken for granted'. In such a circumstance, actors distance themselves from so-called common knowledge (Ishihara and Pascual, 2009), creating a space for them to reflect on their actions in relation to their circumstances.
} 
134 The notion of 'institutional logic' in this paper is used in a similar sense to that of 'habitus' 135 (Bourdieu, 1990) or 'common knowledge' ${ }^{4}$ (Ishihara and Pascual, 2009). According to 136 Bourdieu, habitus is similar to a 'sense of the game'. A player in a game, in our terms an 137 institutional bricoleur, is guided by a 'sense of the game'; but at the same time, the player is not 138 ruled by it. The player still has room to create new strategies and new moves. This is because 139 actors are not merely embedded in one institutional logic but rather in 'multiple habitus' (Seo 140 and Creed, 2002). For instance, an actor, such as a farmer, is not just a 'farmer', but is also 141 engaged with different institutions and social groups such as neighbourhood associations and 142 families, which yield different logics to justify various types of farming actions (Agrawal and 143 Gibson, 1999; Cleaver, 2002; Leach et al., 1999).

144 At the same time, some actors have the capacity to impose their institutional logic as the 145 legitimate worldview and by so doing become the dominant group (Bourdieu, 1989). In this 146 case a given institutional logic assumes a dominant role (Battilana, 2006; Reay and Hinings, 147 2005). This leads us to our second remark: power relations are necessarily involved in any 148 institutional change. When actors are faced with a new institutional context, they can generally 149 contest which institutional logic is to be adopted. In other words, the institutional process 150 involves 'battlefields of legitimacy' 5 where both dominant and marginalised actors challenge as 151 to whose institutional logic is to be applied in guiding the process of institutional change. To 152 this end, the use of the term power' ${ }^{6}$ in this paper refers to the power to 'naturalise' institutional 153 logics (Haugaard, 2008) so that an institution can present itself as if it is a part of the 154 institutional logic as "the way we do things around here" (Foucault, 1977).

155 Of course, some actors may resist the dominant or naturalised institutional logic. However, the 156 possibility of resistance in the context of institutional change should not be romanticized (Van 157 Hecken et al., 2015). We do not deny the possibility of marginalised actors challenging the 158 naturalised institutional logic when institutions are going through transformation. The dominant 159 actors will try to maintain their power by ensuring predictability but marginalised actors also

\footnotetext{
4 Other authors refer to this aspect of institutions as 'institutional context' (Clegg, 2010). We acknowledge that we are not using the term logic in a strict philosophical sense. However, we chose not to use the term 'context' in order to avoid confusion with the social and cultural context in which the actors are embedded which includes wider connotations beyond institutional logic.

5 This notion is a modification of 'battlefields of knowledge' (Long and Long, 1992) in which different actors fight over meaning and moral affiliation in order to gain dominance in a field or domain.

${ }^{6}$ We concur with Haugaard (2008) that we should not look for a definitive definition of power; rather consider it as a 'family resemblance' concept in line with Wittgenstein (1968).
} 
have an interest in adopting counterhegemonic practices to diminish the legitimacy of the dominant group and thus of the dominant institutional logic (Clegg, 2010). However, obviously not all marginalised actors have the capacity to challenge or resist. Depending on their social position within the community, actors have different levels of access to physical and so-called symbolic resources (Bourdieu, 1990). As a result, they do not all have the same capacity to produce effective claims towards naturalising their own institutional logic (Battilana, 2006). In fact, it is often the case that in contrast to more powerful actors, marginalised actors have to bear the burden of proof (Kohn, 2000).

The emerging key message is that institutional bricolage, which focuses on agency embedded inside a set of power relations, enables us to better understand institutional change induced by new environmental governance approaches, such as through PES schemes (Büscher, 2012; Rodríguez-de-Francisco and Budds, 2015; Van Hecken et al., 2015). An institutional logic held by the 'experts' who introduce these approaches, i.e. policy makers and international NGOs, is not always shared with other key actors, e.g. local providers of ecosystem services. In such cases, the introduction of a PES approach to solve an environmental 'externality' provides the opportunity for local actors, both dominant and marginalised, to seek to exercise their agency in various ways. One way is for dominant actors to use this opportunity, e.g. by designing and implementing PES, to extend the legitimacy of their institutional logic and to reproduce their dominance over marginalised actors. But marginalised actors may also seize this opportunity to legitimise their own claims, such as access to certain ecosystem goods or services, demand for land tenure security, etc. which can challenge the power relations within their community (Hendrickson and Corbera, 2015; Shapiro-Garza, 2013). It is thus important to understand the institutional change induced by the introduction of PES schemes as a 'messy' process where bricoleurs continuously fight over the legitimacy of their own institutional logics. In this way, new power struggles arising from the introduction of PES schemes can be interpreted as key social inputs to be considered in their design and implementation (Muradian et al., 2013; Pascual et al., 2014; Van Hecken et al., 2015).

It also follows that institutional change is not merely a process guided by rational calculation in order to achieve an optimal solution over an externality problem. Of course, within this mainstream approach, 'second generation game theorists' incorporate bounded rationality and other types of rationalities, such as interpersonal altruism, fairness, reciprocity and inequity aversion, into a rational choice model (Narloch et al., 2012; Ostrom and Ahn, 2009). However, the problem with this kind of modelling lies in its strict adherence to methodological individualism (Peacock, 2011). Altruistic individuals may choose to act altruistically because their welfare depends on them taking an altruistic action. Here "the tight link between individual 
welfare and choice of action" (Sen, 1982, p. 8) is not broken. As a result, the mainstream approach cannot fully explain other types of institutional logic such as individuals acting as part of a 'community' with which they share a common 'identity' (Martins, 2009).

\section{Case study and methodology}

\subsection{Case study background}

Many CPRs in Japan face the problem of under-use, often termed as the 'Satoyama' problem (Shimada, 2015). Historically, rural communities in Japan were heavily dependent on CPRs, such as communal forests, shallow seas, paddy fields and irrigation channels and thus developed strict institutions to avoid their over-use. These institutions are well-known for the graduated sanctions (McKean, 1992) linked to various social customs and norms that lead rule breakers to face social ostracism (Aoki, 2001). ${ }^{7}$ This suppressed the over-use of CPRs. However, following rural depopulation and economic transformation in Japan, especially since the 1960s (Hasumi, 1990; Torigoe, 2007), the concern regarding CPRs has shifted from over-use to under-use, bringing different environmental challenges (Shimada, 2015). For example, the under-use of communal forests in Japan (called Iriai) causes a loss of biodiversity (Murota and Mitsumata 2004) and 'co-produced' ecosystem services (Palomo et al., 2016), such as regulating services associated with water purification and prevention of land-slides (Morimoto, 2014). Additionally, and in conjunction with the under-use problem, important traditional communal organisations and institutions, once prevalent in hamlets and villages, are being eroded (Onda, 2006). Often, these communities feel themselves heavily burdened with the responsibilities of having to continue to manage the CPRs in traditional ways (Mitsumata et al., 2008). This has led many communities to hand over their CPR management to national or local governments to avoid the burden involved (Mitsumata and Inoue, 2010; Murota and Mitsumata, 2004). Other communities have chosen to co-manage their CPRs by involving new actors from outside the local community. For instance, schemes such as the 'forest volunteer' system, where volunteers are recruited from urban areas to conduct forest management together with forest owners (Yamamoto, 2003), or the terraced paddy field owner system, where urban residents invest financially and/or provide a workforce for the conservation of traditional terraced paddy fields (Maeda and Takao, 2007; Nakajima, 2007).

\footnotetext{
7 This custom was called 'Mura-Hachibu'. This custom ostracises the households that violate the CPR institution from various social groups and social event organised by these groups. As Aoki (2001) argues this ostracism had a detrimental effect on the livelihoods of the villagers, the violation of CPR institutions was limited.
} 
In this evolving social-ecological context, Toyoka City is considered by many as a success story for CPR management through the introduction of its PES scheme (Wittmer and Gundimeda, 2010). The uniqueness of this PES lies in the fact that it has been implemented as part of a

227 policy to conserve the Oriental White Stork, a flagship species. This species, which had become 228 extinct in Japan by the 1980s, was reintroduced in Toyoka City which offered the last available habitat in Japan (Toyoka Municipal Government, 2007a). Oriental White Storks used to live in paddy fields and the surrounding irrigation channels. But the introduction of chemical pesticides and modernization of agricultural infrastructure during the 1950s drastically changed the natural environment, making it less suitable as a stork habitat and adding pressure to other direct drivers such as excessive hunting during the 1920s and 1930s and a decrease in genetic diversity due to the shrinking population. After the reintroduction of the species, various policies were tested to improve the quality of the habitat, mainly targeted at enhancing biodiversity in the paddy fields and surrounding wetlands.

Two types of PES have been implemented in Toyoka; an eco-certification scheme and a co-management scheme. The former, called "the Dance of the Storks" (kounotori no mai), incentivized farmers to switch from conventional to organic farming by providing a premium

240 price and some additional subsidies (Honda, 2008b; Kikuchi, 2006; Toyoka Municipal 241 Government, 2007b). Further, this scheme allows consumers to pay a price premium not just for organic products but also for providing Stork habitat. The co-management scheme is still at a nascent stage and to date has only been implemented in Tai Hamlet, which is our case study site (NGO Wetlands Action Circle for Oriental White Storks, 2012). The hamlet receives limited funds from the local government and an NGO in order to conduct activities for stork conservation (for details see section 4.1.).

247 This paper focuses on the co-management scheme introduced in Tai Hamlet as a pilot project by 248 the local Toyoka government and a local NGO. The hamlet is located in the northern part of 249 Toyoka City (see map in Figure 1). In 2013, it consisted of around 50 households with a 250 population of around 200. The hamlet suffers from an ageing and declining population: one 251 third of the population is over 65 years old, well above the national average of $23 \%$ (Cabinet 252 Office, 2012). Average annual per capita income is about JPY 3.5 million or ca. USD 43,750, ${ }^{8}$ 253 above the national average of JPY 2.9 million or ca. USD 35,750. Before the 1960s, the 254 residents of this hamlet were heavily dependent on CPRs for their livelihoods, especially the 255 rice paddies and shallow sea fishery. However, residents can no longer sustain their traditional

\footnotetext{
${ }^{8}$ Using the conversion rate of USD1= JPY80 (average rate for 2013).
} 
256 livelihoods based on agriculture and fishing, and during the 1960s, the hamlet witnessed 257 significant out-migration of young people to urban areas such as Osaka and Tokyo (Minato 258 Community Centre, 1965). This led to the disbandment of various communal organisations, 259 such as the young men's and women's associations. Further, during the 1960s, the remaining 260 residents started to work outside of the hamlet, including in the adjacent Kinosaki area or the 261 city centre of Toyoka. This diversified not only the income sources of the residents but also 262 their interest in CPR institutions and rice cultivation activities. ${ }^{9}$ In other words, this hamlet has 263 gone through a gradual 'delocalization' process, through which it has become more intimately 264 connected to actors outside the local domain (Ojha et al. 2016). In this social context, the hamlet, 265 or at least its leaders, decided to accept the co-management scheme in 2009 by modifying the 266 existing local institution for the management of its CPRs, particularly the terraced paddy fields.

Figure 1. Location of field study of Tai Hamlet in Toyoka City (Hyogo Prefecture, Japan)

\footnotetext{
${ }^{9}$ Due to this diverse interest, Tai Hamlet failed to implement farmland consolidation despite three attempts since the 1960s. To implement the consolidation project, all the paddy field owners in the hamlet had to agree to share the cost of the project. However, the hamlet failed to reach agreement due to the different interests among the land owners.
} 
271 Fieldwork was carried out in Tai Hamlet between January and December of 2010 and further

272 short-term field visits were undertaken between 2011 and 2013 to follow up on specific issues.

273 Methods included i) in-depth interviews with different key actors, ii) participant observation of

274 various communal events in the hamlet, and iii) observation of meetings between the hamlet

275 leaders and other stakeholders such as government officials and NGOs and meetings among the

276 residents and the leadership council. The KJ method (Kawakita, 1970, 1967) (discussed below)

277 was used for qualitative analysis of the data collected through these three complementary

278 approaches. Discourse analysis was undertaken of government policy documents related to

279 stork conservation and use was made of a municipal database on agricultural statistics.

280 Two types of interviews were undertaken in Japanese. Firstly, a series of non-structured 281 interviews was conducted with residents of the hamlet, especially residents from older 282 generations and members of the leadership council, ${ }^{10}$ regarding the changes in CPR 283 management, their livelihoods, and past as well as current life in the hamlet. The sampling for 284 unstructured interviews used a snowball method. Through these in-depth interviews, we gained 285 basic information on the institutional and organisational structure of the hamlet.

286 Subsequently, strategically targeted interviews were conducted with individuals and groups in 287 relation to each of the various organisations in the community such as the leadership council, 288 neighbourhood groups and fire-fighting group (see a list of communal groups in Appendix 1 289 and an organigram of the hamlet in Appendix 2). At least two group interviews were completed 290 with members of each of the organisations. Initial interviews gathered general information about 291 the organisations as well as information about interactions amongst the residents involved in 292 them. Follow-up interviews were conducted to ask in-depth questions, especially regarding i) 293 the roles that each organisation performs in various communal events and ii) the residents' 294 motivation for participating in these communal events. Since these organisations are organised 295 by gender and age, these group interviews were utilised to collect life histories from each 296 generation and gender. Most of the interviews were carried out through personal visits, i.e.

\footnotetext{
${ }^{10}$ The leadership council is composed of nine members who are elected at the annual meeting by all the households in the hamlet. Once they are elected, they will serve as a 'leader' (yakuin) until they decide to retire. The position of 'hamlet chief' (kucho) is rotated among these nine members and it is this council which makes the decision regarding the hamlet and negotiates with outside parties, such as NGOs and the Toyoka local government.
} 
297 going either to individuals' houses or to the location of the activity, since most of the groups

298 held meetings at least once a month.

299 Participant observation was conducted during various communal events associated with 300 introduction of a 'Storks labour day', e.g. negotiation between the municipal government and 301 the hamlet, as well as with traditional 'labour days', communal festivals, funerals, religious events and annual meetings. This participant observation approach provided an important opportunity to closely observe some of the conflicts inside the community and between the community and other actors. In order to provide additional contextual information, meetings held between the hamlet and the government convened to decide various issues relating to conservation policy were also observed.

The KJ method, developed by Jiro Kawakita, was used to systematically summarise qualitative data (Kawakita, 1970, 1967). The method takes three steps. First, cards are generated by transcribing information from the interviews. One statement is transcribed on each card. Next, cards with similar statements are clustered together. Finally, the clusters are schematised to illustrate the relationships between clusters. This method makes it possible to analyse the vast amount of data collected through different fieldwork methods, such as interviews and participant observation, without losing its meaning; however, a weakness lies in that its clustering can be rather arbitrary (Sato, 2008). The method was chosen because it affords the most freedom in coding, which was necessary in order to understand the complexity of the CPR institutions, especially the arrangements for the collective management of paddy fields and other communal resources in Tai Hamlet. The statements quoted in the following sections have been carefully chosen to represent the clusters of statements created through the KJ method. They illustrate the views shared among the residents in the hamlet rather than the authors attempting to rephrase them in their own words.

\section{4. 'Fitting' the new PES scheme to the local institutional logic in Tai Hamlet}

\subsection{Introduction of the co-management scheme through the Storks labour day}

A co-management scheme, based around a 'Storks labour day', was introduced in Tai Hamlet in 2009. The 'labour day' (Hiyaku), is an institution for managing terraced paddy fields. Cultivating paddy rice requires collective action because it utilises a gravity-fed irrigation system (Onda, 2006). Under the Hiyaku institution, each household has to provide the labour of one person, ideally the head of the household or another adult male, on certain days during the 
year. While there is no formal penalty for non-attendance on labour day, attendance is checked

330 by calling out the name of each household in front of everyone, thus creating peer-pressure that

331 functions as an informal sanctioning mechanism. Further, if there is any absentee, the leaders

332 will go to their house to collect the missing person.

333 The Hiyaku institution is deeply embedded in the social context of the hamlet. Although, the 334 main purpose of the labour day was to maintain various types of infrastructure for rice 335 production, such as irrigation channels and paths to the paddy fields, it also has religious 336 significance. Hiyaku is considered as a day to recreate a spiritual pathway for ancestors so that 337 they may come back to the village during the summer period. Further, the hamlet has a custom 338 called 'selling-off' (Haraimon) which is also associated with Hiyaku. Historically, residents 339 planning to migrate out of the hamlet were obliged to sell their properties, including their house, 340 lands and terraced paddy fields because they could no longer participate in Hiyaku and fulfil 341 their collective action duties. It is thus important to note that Hiyaku as a collective action 342 institution goes beyond the management of CPRs within the hamlet; it also establishes the 'civic' 343 duties of the community and cements the identity of its members.

344 However, the Hiyaku, as a deeply embedded CPR institution, has faced serious challenges as 345 Tai Hamlet has gradually withdrawn from rice cultivation, which stopped completely in 2006.

346 Rice production was ended for various reasons, including the effects of the Japanese 347 Government's agricultural policy introduced to prevent excessive supply of rice, a rapidly 348 ageing and declining population, and damage caused by wild animals, such as boar and deer. It 349 was in this context, that a pair of Oriental White Storks arrived in the hamlet in 2007 and, along 350 with other individual birds, began feeding on the abandoned terraced paddy fields. Because this 351 species feeds on the managed paddy fields and surrounding wetlands, in 2008, a local NGO, the 352 Wetlands Action Circle for Oriental White Storks (WACOWS) ${ }^{11}$ along with the Toyoka 353 municipal government, ${ }^{12}$ approached the hamlet with the intention of resuming management of 354 terraced paddy fields using volunteers from outside the hamlet.

\footnotetext{
11 WACOW was founded by a former Toyoka government staff member who was head of the department in charge of Oriental White Stork conservation. He is also a close friend of the current mayor who is the prime driver for promoting Oriental White Stork conservation in Toyoka.

12 Both WACOW and the local government are considered as outsiders by the residents of Tai Hamlet. From their perspective, the interests of the NGO and the local government do not coincide with those of the hamlet. For the NGO and the local government, the goal is to conserve Oriental White Storks, whereas for the hamlet, the conservation of Oriental White Storks is a means to an end, to revive their community and to bring back the younger generation.
} 
In 2009, the Tai Hamlet leadership council ${ }^{13}$ officially accepted the invitation to become the pilot site for a co-management scheme for terraced paddy fields for Oriental White Storks and

357 the hamlet agreed to add a new version of Hiyaku, in addition to the continuing traditional 358 labour days, known as Kounotori Biyaku, the Storks labour day. This new 'labour day' differs 359 from the traditional days in two ways. Firstly, the new Hiyaku aims to create a habitat for 360 Oriental White Storks, rather than to maintain infrastructure for rice cultivation. Secondly, 361 Hiyaku involves both residents and actors from outside the hamlet, i.e. local NGO and Toyoka 362 local government employees and volunteers from Osaka and Kyoto.

363 The Toyoka local government introduced monetary as well as in-kind payments to compensate 364 for the cost of conservation work for Oriental White Storks, mainly the work on the Storks 365 labour day, and to incentivise community members to participate in the conservation activities. 366 The local government and the NGO also suggested a Storks eco-tourism project in order to raise 367 further income through the conservation of the Storks. The local government and the NGO 368 mobilised funds and brought external experts to help create habitat for Oriental White Storks.

369 When implementing activities inside the hamlet, they always asked for the participation of the $370 \quad$ leadership council.

371 From the commencement of this co-management scheme, the stakeholders were motivated by different interests. The local government and WACOW were motivated by the conservation of 373 Oriental White Storks and their habitat, whereas the hamlet residents, especially the leaders, 374 were more concerned with sustaining their Hiyaku institution and their community as a whole. 375 As mentioned previously, the Hiyaku institution was suffering from the declining population 376 and the end of rice cultivation. Their desire to continue growing rice and to maintain Hiyaku is 377 apparent in the fact that the residents, not just the leaders, often refused to refer to the terraced 378 paddy field as "abandoned paddy fields kousaku-hokichi", and instead called them "fallow-land 379 kyukonchi", despite the fact that they all knew that they would not resume rice cultivation in the 380 near future. This discrepancy in the motivation caused a fierce controversy between the 381 'outsiders', i.e. the local government and WACOW, and the 'insiders', i.e. the residents, when 382 the 'outsiders' tried to prioritise stork conservation goals over the needs of the community as 383 described in the following section.

13 The leadership council conducted all the official negotiations with the Toyoka local government and $\mathrm{NGO}$ and took all decisions related to the hamlet. 
In the following section, based on fieldwork data, we first describe the way external payments were distributed within the community, revealing the influence of the community leaders' local institutional logic on the payment scheme's distributional design. We then discuss the conflict arising due to the rejection of the eco-tourism proposal as part of the PES scheme, by local community leaders who adhered to their own/dominant institutional logic. Finally, we argue that, most significantly, community leaders took the opportunity presented by the introduction of the PES to exercise their power to reinforce their dominant institutional logic in the face of resistance from marginalised groups.

\subsection{PES design and its need to 'fit' the dominant local institutional logic}

The hamlet's involvement in Oriental White Stork conservation, especially through the establishment of the Storks Hiyaku, has brought some financial benefits through: i) a direct financial contribution to the hamlet budget from WACOWS for the collective work that the hamlet undertakes on labour days (e.g. JPY 528,000 ca. USD 6600 in 2012), ii) fees paid by visitors to the hamlet (JPY 500 per visitor amounting to about JPY 130,000 ca. USD 1625 in 2012), iii) payments by visitors to use communal facilities such as the community centre when WACOWS or the local municipal government conducts various activities locally. ${ }^{14}$ Together the annual income received by the hamlet is ca. USD 8,750 , equivalent to about $25 \%$ of the annual hamlet budget.

The funds accruing to the hamlet are distributed through the existing 'hamlet tax' $(K u$-hi $)$, a monthly payment collected from each household to contribute to the hamlet budget. In 2010, the monthly payment ranged from JPY 2,800 to 5,400 (about USD 35-67.5) per month, depending on the income level and financial conditions of each household. The funds received from the conservation were used to waive the hamlet tax for August as compensation for participating in the Hiyaku in July. That is, each household received JPY 2,800-5,400. This distribution mechanism fits the leaders' institutional logic that the communal benefits in connection to the communal property must be distributed to the whole community in an egalitarian way. In order

411 to reveal this institutional logic, we look into the conflict that this raised between the hamlet leaders and the local government and WACOW.

\footnotetext{
14 According to the hamlet's financial report distributed at the annual meeting on $20^{\text {th }}$ December 2012 and some interviews with members of the leadership council.
} 
413 In the Autumn of 2010, the local government and WACOW suggested to the leadership council

414 that the payment, not entirely but partially, should be distributed to individuals. They wanted to

415 incentivise individuals, especially women and young people. Women were the ones mainly

416 involved in implementing various conservation activities other than through the Storks Hiyaku,

417 such as conducting excursions for local schools and tours for visitors. Further, the local

418 government and WACOW were concerned about the sustainability of the co-management

419 scheme itself. The younger generation was deemed to be vital for the survival of this PES

420 scheme over the longer term. However, because the payments were distributed to all the

421 households equally, the women and young people considered them as a payment to the head of

422 household. Some residents felt that they had undertaken the work of managing the paddy fields

423 without receiving any payment or compensation because they were not the head of household.

424 This was especially frustrating for those women who actively participated in activities related to

425 the conservation of the storks.

426 However, when the local government and the NGO suggested distributing the payments to 427 individuals, one of the hamlet leaders refused stating that:

"No way! There is no need to pay individuals. They are making money from the communal property. The money should go to the hamlet not to the individual"

(Community leader during an interview after the meeting with local government and

WACOW on $20^{\text {th }}$ November 2010; own translation). ${ }^{15}$

This statement reveals hamlet leaders' institutional logic. For them, the terraced paddy fields are communal property and the benefit arising from it must be distributed to the households in an egalitarian way, not to the individuals based on their efforts towards the conservation of the habitat for the storks. Part of the institutional logic, i.e. treating the terraced paddy fields as communal property, is manifested by the fact that two households, which do not own any terraced paddy fields, have nevertheless participated in the Hiyaku institution because 'they are part of the hamlet'. ${ }^{16}$ The previously mentioned custom, 'selling-off' (Haraimon), provides

15 Another leader commented that:

"All the payment should go into the hamlet first. If it is to be distributed, it should be to the household not to the individuals, because the households are the ones providing labour for the Hiyaku and other communal duties. To be honest I do not understand why the young people are making a fuss about this. If it is distributed to the household, it is the same. No?" (Interview conducted with community leader on $8^{\text {th }}$ December 2010; own translation).

16 According to the interview conducted with these households which do not own any rice-fields on $11^{\text {th }}$ August 2010. 
further evidence of this institutional logic. A household that moves out of the hamlet cannot

440 hold rights in the communal property because they are no longer part of the community. ${ }^{17}$ It

441 should be noted though that the unit of reference for distributional purposes is the household,

442 not the individual. This is also reflected in various institutions within the hamlet, such as the

443 hamlet tax and the Hiyaku institution. It is the household which provides the labour for Hiyaku

444 and pays the tax.

445 The suggestion by the government and WACOW was especially problematic as it went against

446 the institutional logics. The hamlet leaders felt that the local government and the NGO were

447 prioritising stork conservation rather than their own community. ${ }^{18}$ In other words, the leaders

448 chose to distribute the benefits from the co-management scheme through the hamlet tax system

449 so that they could reinforce the legitimacy of their institutional logic. To this end, the leaders

450 were not just powerless victims but rather actors who were able to utilise their institutional logic

451 to rearrange the PES scheme to 'fit' the local social context, and by doing so subvert some of

452 the original intention of the local government and the NGO that introduced the co-management

453 PES scheme. The local government and the NGO had to pull back from their preference for the

454 individual distributional rule, which might have challenged the legitimacy of the local

455 leadership. In fact, policy makers were heavily dependent on the hamlet leadership council for

456 implementing various activities in the hamlet. ${ }^{1920}$ This reaction by the leaders is not surprising

457 when we consider the fact that they are faced with resistance from young people, who have

458 different interests in the CPR in the context of the 'delocalization' of the hamlet. Before going

459 into the issue of resistance to and challenges faced by the local leaders, the next section reveals

460 how far the leaders were willing to go in reinforcing the legitimacy of their institutional logic.

17 This has been described as the 'duality of land ownership' by many Japanese rural sociologists. This refers to a notion strongly held in Japanese rural societies that all land, including the paddy fields, belongs to the hamlet or the village not just to the individual residents or households (Fujimura, 2001; Torigoe, 1993). In these communities, private land ownership co-exists with communal land ownership (Kada, 1997).

18 According to a personal conversation with the hamlet chief on $20^{\text {th }}$ November 2010.

19 It is our understanding that a majority of the local government staff and the NGO leaders were also in a similar position to the hamlet leaders in their own hamlets. Thus, they were more sympathetic towards the leaders than towards the female or young residents.

20 In the end, policy makers came up with a compromise to organize a study-tour to Lake Shinji as a form of in-kind payment. The tour was organised so that the participants would be able to enjoy sightseeing as compensation for the female residents (According to a personal conversation with local government staff on $15^{\text {th }}$ August 2011). 


\subsection{Conflicts over the distributional design of PES under the dominant local} institutional logic

The economic impacts arising from Oriental White Stork conservation in Toyoka are estimated at USD 12.5 million, or JPY 1 billion per annum (Ohnuma and Yamamoto, 2009). To further expedite the co-management in Tai Hamlet, a proposal was made by the local government and WACOW to develop an eco-tourism project within the hamlet. This proposal to develop stork eco-tourism gained momentum when the local government negotiated with the hamlet over the inclusion of the terraced paddy fields within a wetland area being designated during the $11^{\text {th }}$ Conference of the Parties to the Ramsar Convention in Bucharest (the Lower Maruyama River and surrounding paddy fields). The Ramsar Convention requires protection of wetlands through domestic law (Halls, 1997) which is implemented in Japan through the 'wildlife reserve' (choju-hogoku) scheme under the 2002 Wildlife Protection and Hunting Law (Tanaka, 2008). Once the area is designated as a 'wildlife reserve', any kind of development project or construction work would require permission from the prefectural government and no hunting would be allowed in the area. The stork eco-tourism project was proposed as compensation for restricting future development options in Tai Hamlet.

However, the leaders' response was ambivalent at best. They argued that the eco-tourism project would only benefit certain individuals, particularly two hostel owners. For the hamlet leaders, this was especially problematic since the hostel owners were themselves members of the leadership council. They feared that if they were seen by the rest of the hamlet to be profiting from the communal property and breaking the local institutional logic, their authority could be undermined and their institutional logic delegitimized. For example, one of the hostel owners explicitly said that he did not want to be seen by other residents as gaining personal benefit:

It is not right to make personal profit from the communal property. What do you think others would think? We are already having a difficult time persuading villagers to join the labour days. If I do such a selfish thing, what do you think will happen? (Member of leadership council and hostel owner in his 60s from personal interview on $13^{\text {th }}$ April 2011; own translation).

The hamlet leadership thus declined the eco-tourism development proposal as part of the broader PES scheme. For the leaders, the financial returns from eco-tourism were seen as illegitimate because they would be profiting personally from the 'communal properties'. This 
494 also goes against their institutional logic by which the return from the PES ought to be 495 distributed in an egalitarian way within the community. The two hostel owners, as part of the 496 hamlet leadership, were willing to voluntarily sacrifice an economic opportunity in order to 497 adhere to the local institutional logic. This shows that the leaders are not just economically 498 rational actors aiming at optimizing financial flows for the community from the terraced paddy 499 fields but actors who hold multiple social identities and rationalities within a community context 500 (Schnegg and Linke, 2015). They are capable of reinforcing the legitimacy of the dominant 501 institutional logic. Next, we analyse why such an active re-imposition of the dominant institutional logic was necessary in Tai Hamlet in the context of 'delocalization'.

\subsection{Adherence to the local institutional logic and reproduction of power relations}

As discussed previously, the majority of the hamlet's residents have diversified their income outside the hamlet. This has weakened or more precisely diversified their interests over the maintenance of the traditional CPR and enabled them to challenge the legitimacy of the Hiyaku institution. This is especially the case since the cessation of rice cultivation in 2006. Some residents have openly voiced discontent during the annual community meetings when the schedules for Hiyaku were announced by asking questions such as:

Why do we have to continue to maintain things that we do not use any more? We stopped cultivating rice. It is a waste of time and money. How stupid are we to continue carrying out Hiyaku? (Male resident in his 70 s during the annual meeting on $3^{\text {rd }}$ January 2010; own translation $)^{21}$

Others adopt a subtler resistance strategy by providing a substitute worker on the labour-day, often an elderly female instead of a male labourer. A few households take even further measures to avoid participating in Hiyaku and other communal obligations by obtaining residence cards

21 Other residents express their discontent towards the Hiyaku, one stated that:

I understand hamlet's tradition and the importance of hiyaku and other communal obligations. I want to continue these traditions. But look at the situation. That generation (the generation of the members of leadership council) had nearly 30 people, but ours only has 2 . How can we maintain the same level of work? It is not realistic. It is causing the young generation to move away from the hamlet. (according to an interview with a female resident in her 40s, on $15^{\text {th }}$ August 2010: own translation) 
518 for their younger generation from different areas of Toyoka. This is because people who are not 519 officially residents are not obliged to participate.

520 The legitimacy of the Hiyaku and its institutional logic have been challenged in other ways too. 521 To illustrate this, we note a fierce controversy that occurred in 2012 over the retirement fee paid 522 to the male fire-fighting group, which functions as an extension of the public Fire Department. 523 Although this controversy is not directly related to the broader PES scheme and the 524 management of the CPR institution, it reveals the more general challenges and resistance that 525 the hamlet leaders face. In the hamlet, those who serve in the fire-fighting group receive a 526 retirement fee from the local Fire Department when they retire at the age of 42 . This fee has 527 been paid into the hamlet budget instead of being paid to the individuals involved. The young 528 residents, who serve as members of the fire-fighting group, have argued that individuals have 529 the 'right' to receive the retirement fee individually since they are the ones who served as 530 fire-fighters. They also referred to the fact that in other neighbouring hamlets, the payments are 531 made individually. In response, the leaders fiercely accused the young residents of being 532 'selfish', as from their institutional logic, the retirement fee was paid for a communal activity 533 and thus should not be paid to individuals. They argued that it was the hamlet that runs the 534 fire-fighting group, not the particular individuals who serve in it.

535 Although the young residents did not succeed with their claims, this controversy within the 536 hamlet reveals that they are gaining power to negotiate vis-a-vis their leaders in the hamlet. The 537 younger residents do not adhere to the same institutional logic as the leaders and have shown 538 they are capable of challenging it publicly. This is mainly because the younger generations are 539 not 'educated' in the communal customs and the institutional logic that runs through them. Due 540 to the rapid fall in population, many communal groups have disappeared or become dormant 541 over the past 50 years, such as the youth association and agricultural association. In the past, as 542 the young male residents grew older, they 'graduated' from one group to the next, learning 'the 543 right way of doing things'. However due to the disappearance of these groups and the 544 engagement with the world outside of the hamlet, the younger generation is now exposed to 545 different types of institutional logic, including those that emphasize individualistic norms. ${ }^{22}$ It

\footnotetext{
22 But at the same time, the disappearance of communal groups has negatively impacted the younger generations. Their claim was easily silenced by the leaders as 'ignorant' due to their lack of 'education' in communal customs and the institutional logic. Further, the younger generations are not represented in the leadership council. Previously when the hamlet was cultivating rice, all the young residents joined the agricultural association. If they could prove themselves in this association, they would then be given an opportunity to join the leadership council. However, since this association is now dormant, young people cannot prove themselves, resulting in a stagnation in the membership of the leadership council. In fact,
} 
546 is in this context that the leaders chose to sacrifice their individual gains by forgoing the 547 opportunity presented by the stork eco-tourism project. By showing their adherence to their 548 institutional logic, the leaders are demonstrating that their institutional logic is the 'right way of 549 doing things' in Tai Hamlet in the face of the resistance from the younger generation.

550 This controversy shows that the legitimacy of the dominant institutional logic, that the benefits arising from communal activities should be distributed in an egalitarian manner, has been seriously challenged. The introduction of the PES scheme presented an opportunity for the dominant group, the hamlet leaders, to re-assert their institutional logic as the legitimate view of the world vis-a-vis the marginalised group, the younger generation. In order to do so, the dominant group had to negotiate the distribution mechanism and to forego the eco-tourism project. The case of Tai Hamlet illustrates that although the introduction of the PES scheme contributed to the reproduction of power relations within the hamlet, the dominant actors did not have a free hand in doing so. Rather it is a 'battlefield of legitimacy' where the dominant and marginalised actors fight over whose logic should be applied to a new institutional context, i.e. the new PES scheme.

\section{Conclusions}

563 This paper has applied the idea of institutional bricolage to analyse a situation where PES 564 schemes are introduced, creating a 'messy' institutional transformation process in the context of the management of CPRs. By means of a case study of a hamlet community in Japan, in the

566 context of the conservation of the Oriental White Stork, we have shown that the leaders of the 567 hamlet actively incorporated a PES scheme as a new conservation institution, in light of their 568 own local institutional logic. The case study shows that the community leaders used the introduction of the PES scheme as an opportunity to reinforce the eroding legitimacy of the

570 traditional CPR institution and their dominant institutional logic i.e. that the benefits from the 571 management of the CPR should be shared in an egalitarian way among the households of the 572 community instead of being targeted to individuals. At the same time, we revealed that the 573 leaders are faced with severe resistance from marginalised actors, especially from the younger 574 residents. It is in the context of this resistance that the leaders re-asserted their institutional logic 575 as the legitimate worldview. This case study illustrates how the notion of institutional bricolage

the current leadership council has not had a new member for more than 10 years and the youngest member is already in his 50 s. 
576 can help to unravel the agency and power relations involved in the introduction of a collective 577 PES instrument.

578 This connects with Norgaard's (2010) notion of 'complexity blinder'. He argued that the PES 579 discourse blinds us to the complexity of ecosystems and ecosystem service co-production. Here 580 we go further by uncovering another layer of social-ecological complexity, i.e. the complexity 581 of power relations. We argue that the introduction of a PES scheme as a new institution in any 582 social context induces a 'battlefield of legitimacy' as to who has the right to dictate the new 583 institutional process. Actors produce their own interpretations of the logic of PES and utilise 584 those interpretations to extend their interests and goals, leading to a 'messy' institutional 585 process. In this way, dominant actors, in our case study the leaders of Tai Hamlet in Toyoka 586 City, have managed to impose their interpretation of a fair distribution of the payments onto 587 non-dominant actors, such as the younger residents, closing down alternative interpretations of 588 what is just or fair, providing institutional stability, and (re)producing power relations in the 589 community. The study demonstrates that the institutional change induced by a PES is loaded 590 with subtle political struggles between the dominant and marginalised groups and their 591 associated interests.

592 So then, how can the application of this idea of institutional bricolage help to better capture the 593 implications of PES interventions? First, it calls for the analysis of agency and power relations 594 arising from the implementation of PES schemes. This is especially important considering the 595 popularity of such schemes that embody trade-offs between conservation goals and complex 596 social equity considerations (Milne and Adams, 2012; Pascual et al., 2010). The implementation 597 of PES schemes requires an assessment of agency and power relations in local social-cultural 598 contexts, especially with regard to the perspectives, or institutional logics of marginalised actors 599 (Berbés-Blázquez et al., 2016; Shapiro-Garza, 2013). Second, the notion of institutional 600 bricolage contributes to the re-politicisation of the PES discourse which has often been obscured 601 by neoliberal terminology (Milne and Adams, 2012). In this regard, a key challenge lies in 602 effectively communicating to policy makers the social complexity surrounding the need for the 603 re-politicisation of PES schemes and to get beyond purely technical debates about their design 604 and implementation. This calls for research to engage in the co-production of knowledge with 605 stakeholders to improve the understanding and thus the co-design of PES schemes in order to 606 take account of 'messy' institutional processes. 
Appendix 1. List of communal groups in Tai Hamlet and number of interviews and participant observations conducted in these groups

\begin{tabular}{|c|c|c|}
\hline Communal group & Number of interviews & Participant observation \\
\hline Leadership council & $\begin{array}{l}21 \text { (12 group interviews and } 9 \\
\text { individual interviews) }\end{array}$ & $\begin{array}{l}\text { Annual meetings } \\
\text { Negotiations with the local } \\
\text { government }\end{array}$ \\
\hline Neighbourhood group & $\begin{array}{l}9 \text { ( } 2 \text { group interviews for the } \\
\text { group in the neighbourhood } \\
\text { where the lead author resided, } \\
\text { and } 7 \text { interviews for each } \\
\text { neighbourhood group chief) }\end{array}$ & $\begin{array}{l}\text { Seasonal religious events/ } \\
\text { cleaning events }\end{array}$ \\
\hline Agricultural association & $\begin{array}{l}5 \text { ( } 2 \text { individual interviews with } \\
\text { the representative of the } \\
\text { Agricultural association and } 3 \\
\text { with individual farmers who } \\
\text { cultivated rice until 2006) }\end{array}$ & N.A. \\
\hline Fishery association & $\begin{array}{l}5 \text { ( } 2 \text { group interviews with the } \\
\text { members, } 2 \text { individual } \\
\text { interviews with the } \\
\text { representative of the Fishery } \\
\text { association, } 1 \text { individual } \\
\text { interview with the holder of } \\
\text { fishing rights) }\end{array}$ & $\begin{array}{l}\text { Seaweed collection conducted } \\
\text { during March and April/ Seaweed } \\
\text { festival organised by the } \\
\text { community }\end{array}$ \\
\hline Fire-fighting group & $\begin{array}{l}5 \text { ( } 2 \text { group interviews, } 3 \\
\text { individual interviews) }\end{array}$ & $\begin{array}{l}\text { Monthly training for the } \\
\text { fire-fighting group }\end{array}$ \\
\hline Female fire-fighting group & $\begin{array}{l}6 \text { ( } 2 \text { group interviews, } 4 \\
\text { individual interviews) }\end{array}$ & $\begin{array}{l}\text { Monthly training for the } \\
\text { fire-fighting group }\end{array}$ \\
\hline Night watch & N.A. & Rotational night-watch activities \\
\hline Elderly club & 2 (2 group interviews) & \\
\hline Religious group & 2 (2 group interviews) & $\begin{array}{l}\text { Religious events, such as 'Bon' } \\
\text { during August }\end{array}$ \\
\hline Funeral group & 2 (2 group interviews) & Funeral in August 2010 \\
\hline
\end{tabular}


612

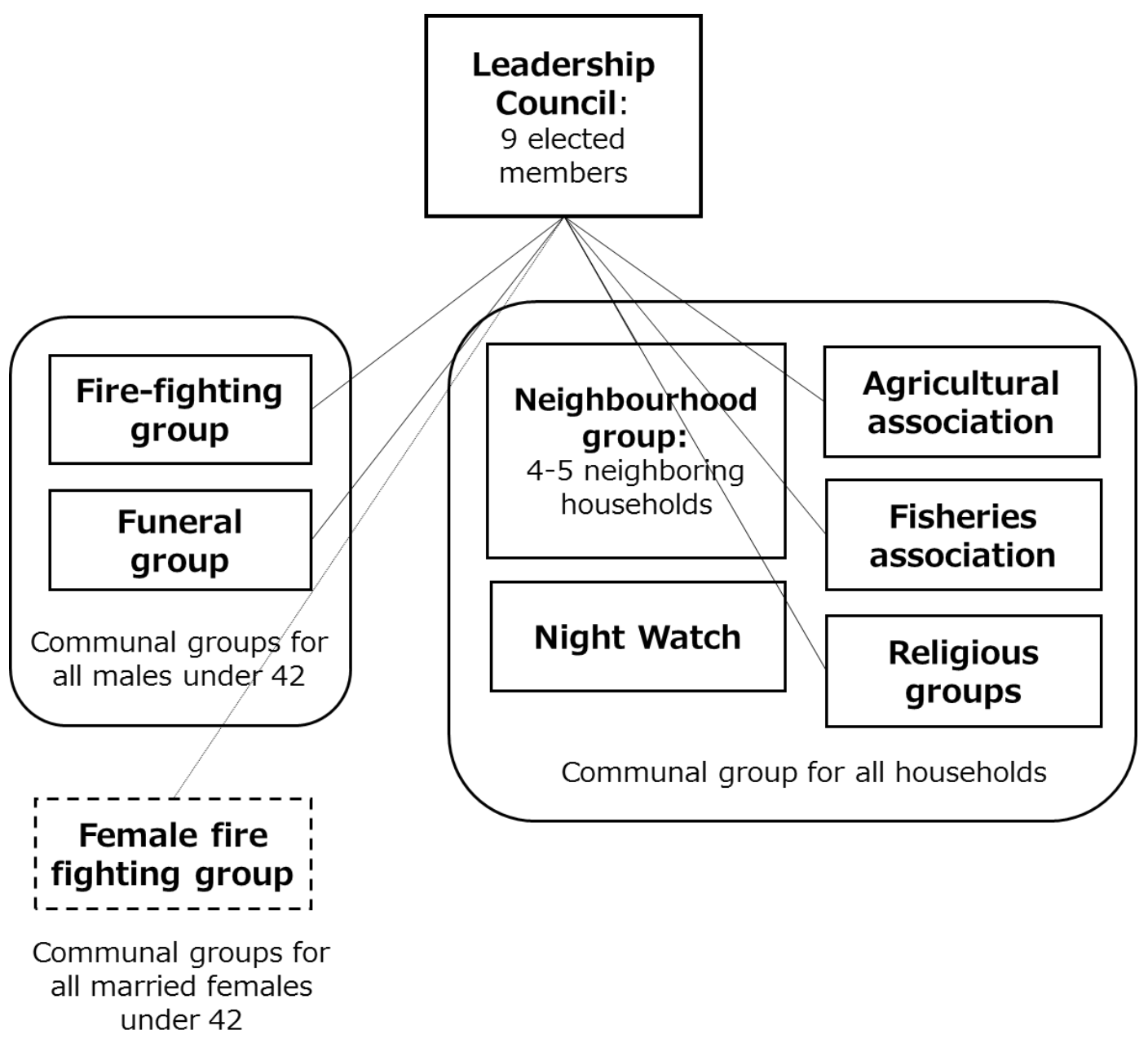

613

614

615 


\section{References}

Agrawal, A., Gibson, C.C., 1999. Enchantment and disenchantment: the role of community in natural resource conservation. World Dev. 27, 629-649.

Aoki, M., 2001. Community norms and embeddness: A game-theoric approach, in: Hayami, Y., Aoki, M. (Eds.), Communities and Markets in Economic Development. Oxford University Press, Oxford, pp. 97-128.

Baker, T., Nelson, R.E., 2005. Creating Something from Nothing: Resource Construction through Entrepreneurial Bricolage. Adm. Sci. Q. 50, 329-366. doi:10.2189/asqu.2005.50.3.329

Berbés-Blázquez, M., González, J.A., Pascual, U., 2016. Towards an ecosystem services approach that addresses social power relations. Curr. Opin. Environ. Sustain. 19, 134-143.

Bourdieu, P., 1990. The logic of practice. Stanford University Press.

Bourdieu, P., 1989. Social space and symbolic power. Sociol. theory 7, 14-25.

Büscher, B., 2012. Payments for ecosystem services as neoliberal conservation: (Reinterpreting) evidence from the Maloti-Drakensberg, South Africa. Conserv. Soc. 10, 29.

Cabinet Office, 2012. White paper for aging society.

Chan, K.M.A., Balvanera, P., Benessaiah, K., Chapman, M., Díaz, S., 2016. Why protect nature? Rethinking values and the environment. Proc. Natl. Acad. Sci. 113. doi:10.1073/pnas.1525002113

Christiansen, Larke, H., Lounsbury, M., 2013. Strange Brew: Bridging Logics Via Institutional Bricolage and the Reconstitution of Organizational Identity: Institutional Logics in Action, Part B [WWW Document]. Res. Sociol. Organ.

Cleaver, F., 2012. Development through bricolage: rethinking institutions for natural resource management., Development through bricolage: rethinking institutions for natural resource management. Routledge. 
644 Cleaver, F., 2002. Reinventing institutions: Bricolage and the social embeddedness of natural 645 resource management. Eur. J. Dev. Res. 14, 11-30. doi:10.1080/714000425

646 Clegg, S., 2010. The State, Power, and Agency: Missing in Action in Institutional Theory? J. 647 Manag. Inq. 19, 4-13.

648 Crawford, S.E.S., Ostrom, E., 1995. A grammer of institution. Am. Polit. Sci. Rev. 89, $649 \quad 582-600$.

650 De Koning, J., Cleaver, F., 2012. Institutional bricolage in community forestry: an agenda for 651 future research, in: Forest-People Interfaces. Springer, pp. 277-290.

Douglas, M., 1986. How institutions think. Syracuse University Press.

653 Emirbayer, M., Mische, A., 1998. What Is Agency? Am. J. Sociol. 103, 962-1023.

Fabinyi, M., Evans, L., Foale, S.J., 2014. Social-ecological systems, social diversity, and power:

Foucault, M., 1977. Discipline and punish: The birth of the prison. Vintage.

Fujimura, M., 2001. What it does it mean to have "collective property"? (in Japanese), in: Miyauchi, T. (Ed.), Sociology of Commons. Shinyosha, Tokyo.

Galvan, D.C., 2004. The state must be our master of fire: How peasants craft culturally sustainable development in Senegal. Univ of California Press.

Hall, K., Cleaver, F., Franks, T., Maganga, F., 2014. Capturing Critical Institutionalism: A Synthesis of Key Themes and Debates. Eur. J. Dev. Res. 26, 71-86.

Halls, A.J., 1997. Wetlands, biodiversity and the Ramsar convention: the role of the convention on wetlands in the conservation and wise use of biodiversity, in: Ramsar Convention

Hasumi, O., 1990. Anguishes of Japanese rural villages: The national policy and the social 669 changes (in Japanese). Yushindo, Tokyo, Japan. 
671

672

673

674

675

676

677

678

679

680

681

682

683

684

685

686

687

688

689

690

691

692

693

694

695

696

697

698

Hendrickson, C.Y., Corbera, E., 2015. Participation dynamics and institutional change in the Scolel Té carbon forestry project, Chiapas, Mexico. Geoforum 59, 63-72. doi:10.1016/j.geoforum.2014.11.022

Honda, Y., 2008a. Coexistence with Orietanl White Storks - From a forced coexitence to a communal belongings (in Japanese) . Genjinsha.

Honda, Y., 2008b. Re-thinking re-introduction of Oriental White Storks and co-habitation with this birds (in Japanese). Genjin-sha, Tokyo.

Hotimsky, S., Cobb, R., Bond, A., 2006. Contracts or scripts? A critical review of the application of institutional theories to the study of environmental change. Ecol. Soc. 11, 41.

Hyogo Prefectural Government, 2009. Action Plan for the Promotion of Organic Farming in Hyogo Prefecutre (in Japanese).

Ishihara, H., Pascual, U., 2009. Social capital in community level environmental governance: A critique. Ecol. Econ. 68, 1549-1562.

Kada, Y., 1997. Multiple ownership derived From everyday life practice: Ownership and utilization of communal resources around the Lake Yogo (in Japanese). Japanese Assoc. Environ. Sociol. 3, 72-85.

Kawakita, J., 1970. For Creative Ideas 2: KJ method (in Japanese). Chuo-Kouronsha.

Kawakita, J., 1967. For Creative Ideas (in Japanese). Chuo-Koronsha.

Kikuchi, N., 2006. Revival of the Oriental White Storks (in Japanese). Tokyo University Press, Tokyo, Japan.

Kohn, M., 2000. Language, Power, and Persuasion: Toward a Critique of Deliberative Democracy. Constellations 7, 408-429. doi:10.1111/1467-8675.00197

Leach, M., Mearns, R., Scoones, I., 1999. Environmental entitlements: dynamics and institutions in community-based natural resource management. World Dev. 27, 225-247.

Lévi-Strauss, C., 1966. The savage mind. University of Chicago Press.

Long, N., Long, A., 1992. Battlefields of knowledge : the interlocking of theory and practice in social research and development. Routledge. 
699

700

701

702

703

704

705

706

707

708

709

710

711

712

713

714

715

716

717

718

719

720

721

722

723

724

725

726

Lounsbury, M., Glynn, M.A., 2001. Cultural entrepreneurship: stories, legitimacy, and the acquisition of resources. Strateg. Manag. J. 22, 545-564. doi:10.1002/smj.188

Maeda, M., Takao, K., 2007. Connecting rural and urban communities: Terraced paddy field owner system (in Japanese). Maruzen, Tokyo.

Martins, N., 2009. Rules, social ontology and collective identity. J. Theory Soc. Behav. 39, 323-344.

McCay, B.J., 2002. Emergence of Institutions for the Commons: Contexts, Situations, and Events. The Drama of the Commons 361-402.

McKean, M.A., 1992. Management of traditional common lands (Iriaichi) in Japan. Mak. commons Work. Theory, Pract. policy 1st editio, 63-98.

Milne, S., Adams, B., 2012. Market Masquerades: Uncovering the Politics of Community-level Payments for Environmental Services in Cambodia. Dev. Change 43, 133-158.

Minato Community Centre, 1965. History of Minato village (in Japanese).

Mitsumata, G., Inoue, M., 2010. Possibility of local commons: New relationship between self-governance and envrionment (in Japanese). Mineruva Shobo.

Mitsumata, G., Morimoto, S., Murota, T., 2008. The Frontiers of the Study of Commons: Common World of Mountains/Sea/Rivers (in Japanese). Tokyo University Press, Tokyo.

Morimoto, M., 2014. Degradation of ecosystem service caused by the underuse of commons (in Japanese). Sociol. Theory Methods 29, 261-276.

Mosse, D., 1997. The symbolic making of a common property resource: history, ecology and locality in a tank irrigated landscape in South India. Dev. Change 28, 467-504.

Muradian, R., Arsel, M., Pellegrini, L., Adaman, F., Aguilar, B., Agarwal, B., Corbera, E., Ezzine de Blas, D., Farley, J., Froger, G., Garcia-Frapolli, E., G??mez-Baggethun, E., Gowdy, J., Kosoy, N., Le Coq, J.F., Leroy, P., May, P., M??ral, P., Mibielli, P., Norgaard, R., Ozkaynak, B., Pascual, U., Pengue, W., Perez, M., Pesche, D., Pirard, R., Ramos-Martin, J., Rival, L., Saenz, F., Van Hecken, G., Vatn, A., Vira, B., Urama, K., 2013. Payments for ecosystem services and the fatal attraction of win-win solutions. Conserv. Lett. 6, 274-279. 
Muradian, R., Corbera, E., May, P.H., 2010. Reconciling theory and practice: An alternative conceptual framework for understanding payments for environmental services. Ecol. Econ. $69,1202-1208$.

Murota, T., Mitsumata, G., 2004. Iriai Forest and Commons: Sustainable Shared Forest (in Japanese). Nihon-Hyoronsha, Tokyo.

Nakajima, M., 2007. Terraced paddy fields owener system: its development, typology and evaluation (in Japanese). Connect. Rural urban areas 57, 26-35.

Narloch, U., Pascual, U., Drucker, A., 2012. Collective Action Dynamics under External Rewards: Experimental Insights from Andean Farming Communities. World Dev. 40, 2096-2107.

NGO Wetlands Action Circle for Oriental White Storks, 2012. Challenges of Tai hamlet (in Japanese).

Norgaard, R.B., 2010. Ecosystem services: From eye-opening metaphor to complexity blinder. Ecol. Econ. 69, 1219-1227.

North, D.C., 1990. Institutions, institutional change and economic performance. Cambridge university press.

Ohnuma, A., Yamamoto, M., 2009. Economic analysis of returning the white storks to the wild in Toyooka City, Hyogo Prefecture: economic rationale for adopting white stork friendly farming method and the effect of returning the white storks to the wild on the local economy (in Japanese). J. Assoc. Mita 102, 191-211.

Ojha, H.R., Ford, R., Keenan, R.J., Race, D., Carias Vega, D., Baral, H., Sapkota, P., 2016. Delocalizing Communities: Changing Forms of Community Engagement in Natural Resources Governance. World Dev. xx. doi:10.1016/j.worlddev.2016.06.017

Onda, M., 2006. Reciprocal society: Ethnographical sociology of "Yui", "Moyai" and "Tetsudai" (in Japanese). Sekai Shisou-sha, Kyoto.

Osborne, T.M., 2011. Carbon forestry and agrarian change: access and land control in a Mexican rainforest. J. Peasant Stud. 38, 859-883. doi:10.1080/03066150.2011.611281

Ostrom, E., 1992. Crafting Institutions for Self-Governing Irrigation Systems, ICS Press. Institute for Contemporary Studies. doi:10.1002/rrr.3450080314 
Ostrom, E., 1990. Governing the commons: The evolution of institutions for collective action. Cambridge university press.

Ostrom, E., Ahn, T.K., 2009. The meaning of social capital and its link to collective action, in: Svendsen, G.T., Svendsen, G.L.H. (Eds.), Handbook of Social Capital: The Troika of Sociology, Political Science, and Economics. Edward Elgar, Cheltenham, Glos, UK; Northampton, MA, p. xvii, 460 .

Palomo, I., Felipe-Lucia, M.R., Bennett, E.M., Martín-López, B., Pascual, U., 2016. Chapter Six - Disentangling the Pathways and Effects of Ecosystem Service Co-Production, in: Advances in Ecological Research. pp. 245-283.

Pascual, U., Muradian, R., Rodriguez, L.C., Duraiappah, A., 2010. Exploring the links between equity and efficiency in payments for environmental services: A conceptual approach. Ecol. Econ. 69, 1237-1244. doi:10.1016/j.ecolecon.2009.11.004

Pascual, U., Phelps, J., 2014. Social equity matters in payments for ecosystem services. ....

Pascual, U., Phelps, J., Garmendia, E., Brown, K., Corbera, E., Martin, A., Gomez-Baggethun, E., Muradian, R., 2014. Social Equity Matters in Payments for Ecosystem Services. Bioscience 64, 1027-1036.

Peacock, M., 2011. Sen's apples: Commitment, agent relativity and social norms. Ration. Mark. Morals 2, 35-47.

Reay, T., Hinings, C.R., 2005. The recomposition of an organizational field: Health care in Alberta. Organ. Stud. 26, 351-384. doi:10.1177/0170840605050872

Rodríguez-de-Francisco, J.C., Budds, J., 2015. Payments for environmental services and control over conservation of natural resources: the role of public and private sectors in the conservation of the Nima Watershed, Colombia. Ecol. Econ. 117, 295-302.

Rodríguez de Francisco, J.C., Budds, J., Boelens, R., 2013. Payment for Environmental Services and Unequal Resource Control in Pimampiro, Ecuador. Soc. Nat. Resour. 26, 1217-1233.

Sato, I., 2008. Method for analyising qualitative data (in Japanese). Shiyosha, Tokyo.

Schnegg, M., Linke, T., 2015. Living institutions: Sharing and sanctioning water among pastoralists in Namibia. World Dev. 68, 205-214. doi:10.1016/j.worlddev.2014.11.024

Schneiberg, M., 2002. Organizational Heterogeneity and the Production of New Forms: Politics, Social Movements and Mutual Companies in American Fire Insurance, 1900-1930, in: 
Lounsbury, M., Ventresca, M.J., Schneiberg, M. (Eds.), Research in the Sociology of Organizations. Emerald Group Publishing Limited, pp. 39-89. doi:doi:10.1016/S0733-558X(02)19002-1

Sen, A., 1982. Choice, welfare, and measurement, 1st MIT Pr. ed. MIT Press, Cambridge, Mass.

Seo, M.-G., Creed, W.E.D., 2002. Institutional Contradictions, Praxis, and Institutional Change: a Dialectical Perspective. Acad. Manag. Rev. 27, 222-247.

Sewell, W.H.J., 1992. A Theory of Structure: Duality, Agency, and Transformation. Am. J. Sociol. 98, 1-29.

Shapiro-Garza, E., 2013. Contesting the market-based nature of Mexico's national payments for ecosystem services programs: Four sites of articulation and hybridization. Geoforum 46, 5-15. doi:10.1016/j.geoforum.2012.11.018

Shimada, D., 2015. Multi-level natural resources governance based on local community: A case study of semi-natural grassland in Tar??ji, Nara, Japan. Int. J. Commons 9, 486-509.

Tanaka, K., 2008. Legal framework concerning wetland conservation and its challenges (in Japanese). Annu. Econ. Reveiw by Nagasaki Univ. 24, 51-74.

Torigoe, H., 2007. Researching Rural Community (in Japanese). Nousangyoson Bunka Kyokai, Tokyo.

Torigoe, H., 1993. Sociology of households and villages (in Japanese). Sekaishisosha, Tokyo.

Toyoka Municipal Government, 2007a. Toyoka environmental economic strategy (in Japanese).

Toyoka Municipal Government, 2007b. History of Oriental White Storks (in Japanese).

Van Hecken, G., Bastiaensen, J., Windey, C., 2015. Towards a power-sensitive and socially-informed analysis of payments for ecosystem services (PES): Addressing the gaps in the current debate. Ecol. Econ. 120, 117-125.

Vatn, A., 2010. An institutional analysis of payments for environmental services. Ecol. Econ. 69, $1245-1252$.

Wade, R., 1989. Village republics. Cambridge University Press.

Wittgenstein, L., 1968. Wittgenstein's Family Resemblance. Philos. Investig.

Wittmer, H., Gundimeda, H., 2010. TEEB For local and regional policy makers. 
815 Yamamoto, S., 2003. Reorganization of irrigation system due to land improvement: A

816 Case-study of Izeya System at Ogi District in Otsu City, Shiga Prefecture (in Japanese).

817 Japanese Assoc. Environ. Sociol. 9, 185-201.

818 Young, O.R., 2002. Institutional interplay: The environmental consequences of cross-scale 819 interactions. The drama of the commons 263-291.

820 